\title{
COMPUTER VISION UNTUK PENGENALAN OBYEK PADA PELUNCURAN ROKET KENDARAAN TEMPUR
}

\author{
Nur Ficky Ardiansyah'², Abdur Rabi' ${ }^{1}$, Desyderius Minggu' ${ }^{2}$, Wahyu Dirgantara' \\ ${ }^{1}$ Jurusan Teknik Elektronika UNMER Malang \\ ${ }^{2}$ Departemen Optik dan Hidrolik Lembaga Pengkajian Teknologi TNI-AD \\ Email: ardianurfiki89@gmail.com
}

\begin{abstract}
Abstrak
Dengan perkembangan teknologi terutama bidang elektronika, Modernisasi alat utama sistem senjata yang dimiliki oleh TNI-AD dapat diwujudkan. Penerapan Apliksi Computer Vision untuk Pendeteksian Obyek Tank merupakan salah satu wujud nyata untuk menambah kekuatan persenjataan TNI-AD. Sistem pengenalan tank ini dapat digunakan pada peluncur roket anti tank dengan menggunakan kamera dengan computer vision. Objek/target yang berada disuatu tempat pada jarak tertentu dapat dideteksi tank atau bukan, metode image processing melalui proses morfologi citra untuk pengenalan objek dilanjutkan dengan proses perhitungan kecepatan tank yang melintas untuk menghasilkan informasi waktu yang diperlukan dari target/sasaran menuju titik penghancuran. Software yang digunakan adalah Matlab 2013. Masukan gambar dari kamera diproses pada Personal Computer (PC) dan informasi target/sasaran ditampilkan pada monitor
\end{abstract}

Kata Kunci: image processing, computer vision, matlab, Classification Trees And Regression Trees.

\section{Pendahuluan}

Perkembangan ilmu pengetahuan dan teknologi yang Perkembangan yang sangat pesat dalam dunia teknologi pada umumnya dan teknologi Alusista pada khususnya, proses pengolahan citra telah dimanfaatkan dalam teknologi militer, seperti untuk kegiatan pengintaian maupun pengamanan[1]. Sistem pengenalan obyek tank merupakan bagian dari sistem pengintaian terhadap suatu obyek atau tank musuh yang dilakukan oleh kamera video untuk mendapatkan suatu situasi medan yang menjadi target pengintaian.

Tank merupakan kendaraan tempur lapis baja beroda rantai yang digunakan untuk mendukung pasukan Kavaleri dalam operasi tempur. Manuver tank dimedan operasi selalu diwaspadai, karena tank memiliki daya kejut dan daya tembak yang dapat merusak konsentrasi lawan. Oleh karena itu, arah datangnya tank selalu menjadi faktor dominan untuk diketahui atau dideteksi sejak awal[2]. Dalam hal ini dalam melakukan pengintaian masih menggunakan personel untuk mengawasi daerah datangnya tank musuh. Kondisi dalam pengintaian ini membutuhkan konsentrasi, tenaga personel dan logistik yang lebih banyak. Maka hal ini merugikan satuan dalam aspek waktu, logistik dan tenaga[3]. Disamping itu personel yang melakukan pengintaian dapat mengalami kelelahan yang dapat menyebabkan kelalaian sehingga menyebabkan terjadinya korban jiwa. Penulis memiliki ide untuk menggantikan tugas personel tersebut dengan menggunakan alat pengintai untuk mendeteksi tank secara otomatis. Dalam hal ini yang digunakan dalam obyek penelitian adalah tank Leopard.

Pengolahan Citra (Image Processing) merupakan bidang yang berhubungan dengan proses transformasi citra/Gambar (image)[4][5]. Proses ini bertujuan untuk mendapatkan kualitas citra yang lebih baik. Sedangkan Pengenalan Pola (Pattern Recognition), bidang ini berhubungan dengan proses identifikasi obyek pada citra atau interpretasi citra. Proses ini bertujuan untuk mengekstrak informasi/pesan yang disampaikan oleh Gambar atau citra[6]. Tujuan penelitian ini adalah untuk membuat sistem pengenalan obyek tank menggunakan computer vision untuk mendeteksi obyek dengan parameter akurasi dan jarak[7]. 


\section{Metode Penelitian}

Perancangan dan pembuatan aplikasi computer vision untuk pengenalan obyek tank pada peluncur roket ini dimulai diagram alir (flowchart) menggambarkan aliran dari data yang akan diolah oleh data processing pada personal computer (PC)[8][9].

Variabel penelitian yang digunakan pada penelitian ini adalah parameter yang ditentukan sebagai indikator perbandingan. Akurasi pengenalan obyek yaitu untuk mengukur tingkat kepekaan sistem dalam mengidentifikasi obyek sebagai tank bila dibandingkan dengan benda lain. Software Matlab 2013. Metode Classification Trees And Regression Trees

Jarak yaitu perancangan ini jarak pengenalan tank merupakan parameter yang digunakan untuk menguji jarak antara obyek dengan sistem berada. Orientation (x1) yaitu sudut (dalam derajat mulai dari -90 sampai 90 derajat) antara sumbu $x$ dan sumbu utama elips yang memiliki sama kedua-momen sebagai wilayah tersebut. Extent (x2) yaitu skalar yang menentukan rasio pixel di daerah untuk pixel dalam total berlari kotak. ConvexArea (x3) yaitu skalar yang menentukan jumlah pixel dalam 'ConvexImage[10][11]. Area (x4) yaitu skalar jumlah aktual pixel di wilayah tersebut. EquivDiameter $(x 5)$ yaitu skalar yang menentukan diameter lingkaran dengan area yang sama dengan yang wilayah. Solidity $(\mathrm{x} 6)$ yaitu skalar menentukan proporsi pixel dalam convex hull yang juga di wilayah tersebut. Perimeter ( $x 7$ ) yaitu skalar jarak sekitar batas daerah. Regionprops menghitung perimeter dengan menghitung jarak antara masingmasing pasangan berdampingan pixel sekitar perbatasan wilayah[12][13].

\section{Skema Arsitektur Perancangan}

Perancangan dan pembuatan alat yang digabungkan menjadi satu sistem kerja terdiri dari tiga bagian besar yaitu bagian input atau masukan, bagian process atau pemroses dan bagian output atau keluaran.

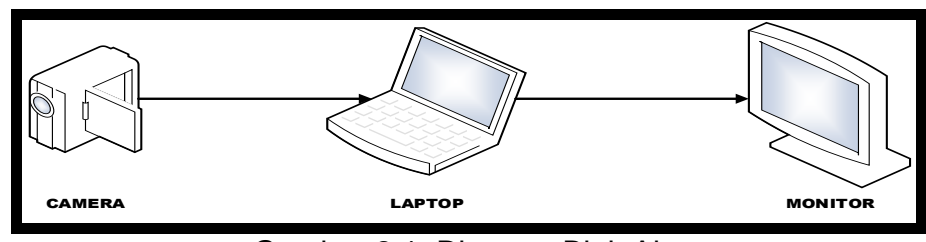

Gambar 2.1. Diagram Blok Alat

\section{Perancangan Desain Perangkat Keras (Hardware)}

Perencanaan alat yang berupa perangkat keras (hardware) adalah perancangan desain seperti yang ditunjukan dengan Gambar 2.2

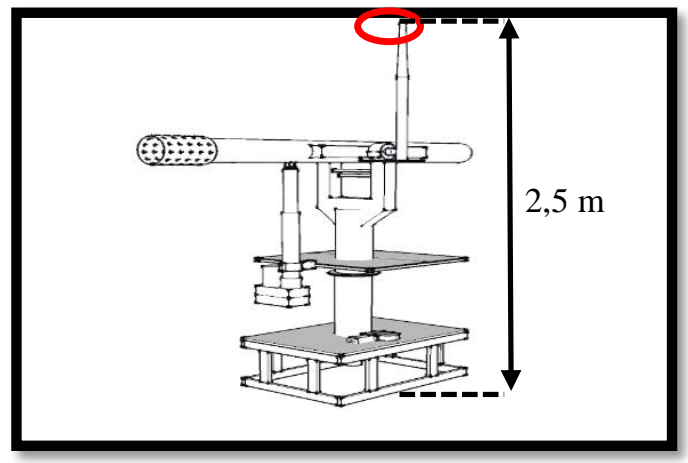

Gambar 2.2. Desain Perangkat Keras

\section{Perancangan Perangkat Lunak (Software)}

Perancangan perangkat lunak adalah perancangan bahasa program yang akan ditanamkan pada personal computer (PC) yang akan dijalankan untuk mengontrol sistem sehingga dapat bekerja sesuai dengan perencanaan perancangan yang direncanakan. 


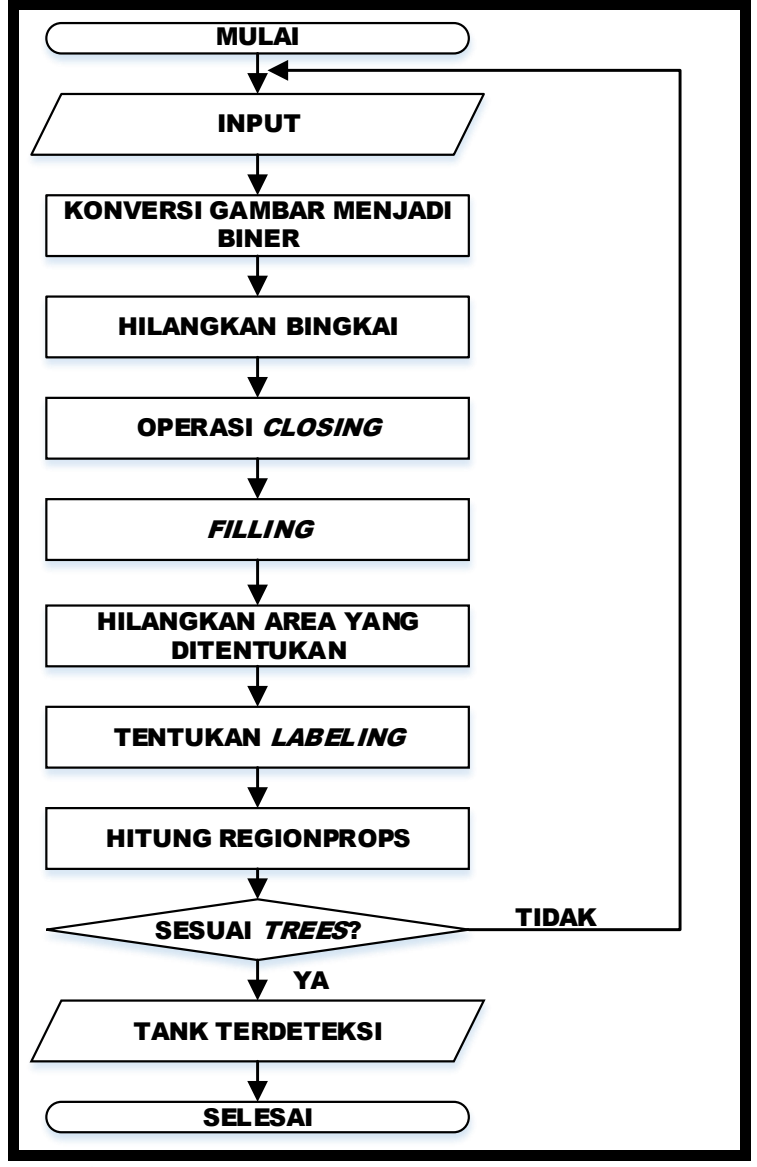

Gambar 2.3. Diagram Alir Perangkat Lunak

\section{Perancangan Pohon Klasifikasi (Classification Trees And Regression Trees)}

Proses pembuatan pohon klasifikasi diawali dengan pengumpulan data ciri obyek seperti tank, mobil maupun orang dengan menggunakan regionprops pada Matlab[14]. Regionprops merupakan sebuah fungsi yang dimiliki Matlab untuk mengukur sekumpulan properti-properti dari setiap region yang telah dilabeli dalam matriks label $L$.

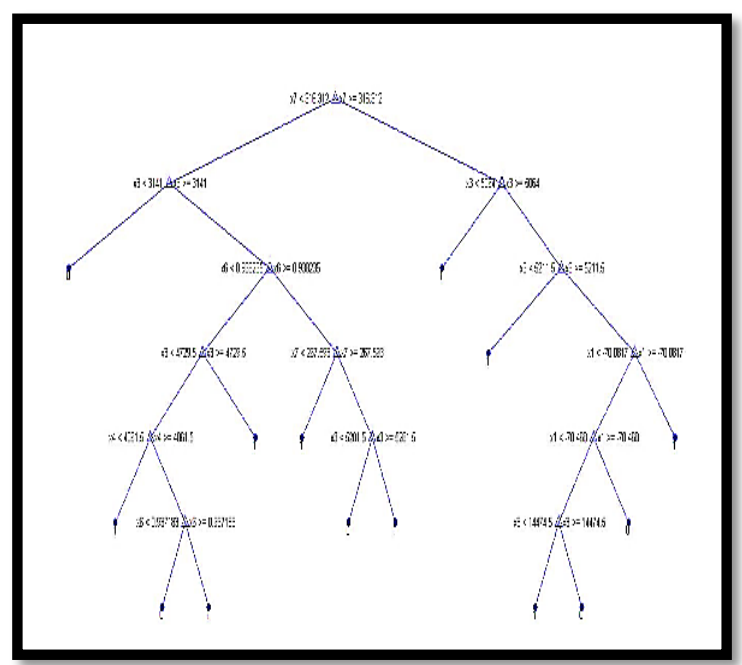

Gambar 2.4. Diagram Alir Sistem Kerja Alat.

Computer Vision Untuk Pengenalan Obyek Pada Peluncuran Roket Kendaraan Tempur (Nur Ficky Ardiansyah) 


\section{Sistem Kerja Alat}

Pada sistem kerja alat, keseluruhan rangkaian yang sudah dirakit dirangkai menjadi satu rangkaian sistem yang saling mendukung sehingga peralatan yang dirancang dapat bekerja/aktif sesuai dengan fungsi yang telah direncanakan[15][16].

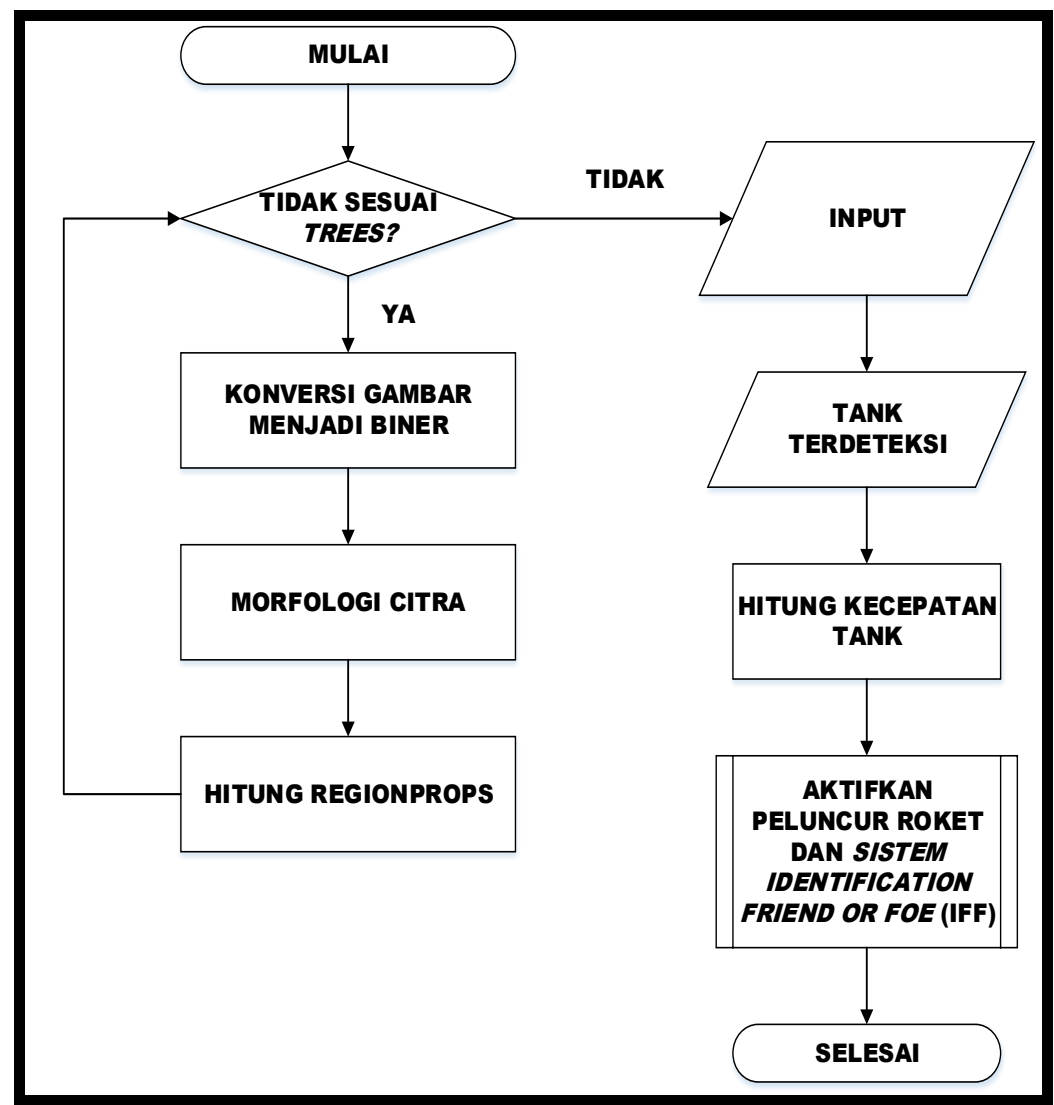

Gambar 3.5. Diagram Alir Sistem Kerja Alat.

\section{Hasil dan Analisis}

3. 1 Hasil Pengujian

Hasil Pengujian Statis

Proses pengujian statis ini dilakukan untuk mengetahui persentase error yang terjadi pada pohon klasifikasi / trees dalam pengenalan obyek. Proses pembuatan pohon klasifikasi ini dimulai dengan pengumpulan nilai - nilai regionprops yang meliputi orientation, extent, convexarea, area, equivdiameter, solidity, dan perimeter dengan menggunakan program deskriptor.

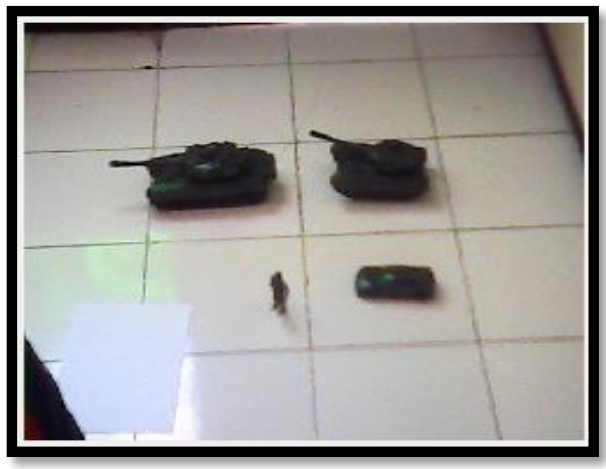

Gambar 3.1. Hasil Capture Obyek Kamera

Computer Vision Untuk Pengenalan Obyek Pada Peluncuran Roket Kendaraan Tempur (Nur Ficky Ardiansyah) 
Gambar 3.1 merupakan hasil dari capture obyek dari kamera. Hasil pengurangan gambar kamera dengan gambar latar belakang kemudian akan dikonversikan menjadi biner seperti pada gambar 3.2.

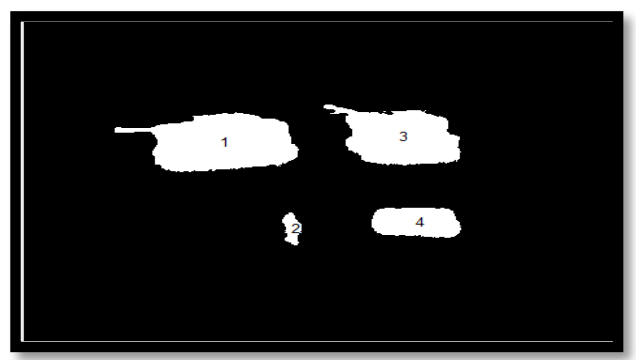

Gambar 3.2. Hasil Konversi Ke Biner

Gambar 3.2 merupakan gambar hasil pengurangan dari gambar latar dengan gambar yang ditangkap kamera secara berurutan yang kemudian dikonversikan menjadi gambar biner. Proses setelah gambar dijadikan biner maka akan dihiting nilai - nilai regionprops[17].

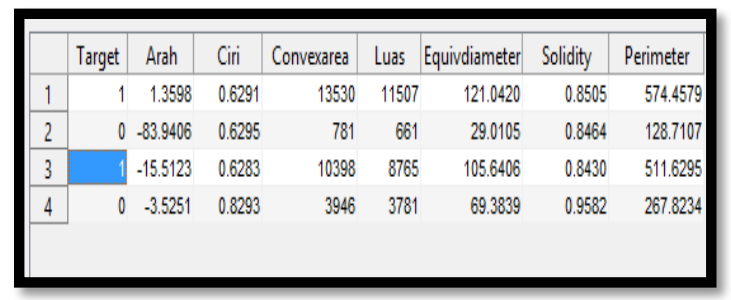

Gambar 3.3. Nilai Regionprops

Nilai - nilai yang telah dihitung oleh regionprops dalam bentuk pixel. Pixel yang kepanjangan dari picture element atau elemen gambar merupakan bagian terkecil dari suatu gambar digital. Nilai tersebut kemudian digabungkan menjadi satu yang nantinya akan menjadi pohon klasifikasi / trees[18]. Pohon klasifikasi selanjutnya diuji untuk menentukan prosentase error dan mendapatkan tingkat keberhasilan yang dihitung menggunakan program Matlab. Toleransi error yang diharapkan maksimal 5\%. Data yang digunakan sebanyak 1043 dengan error sebanyak 9 data Seperti yang terlihat pada gambar 3.4.

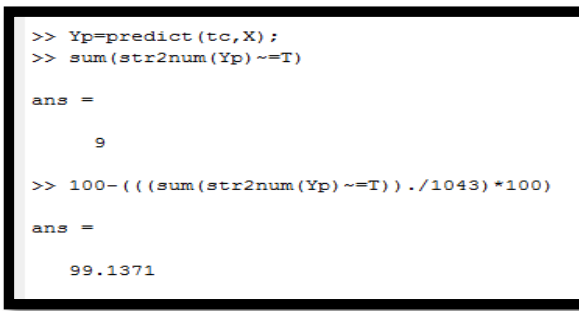

Gambar 3.4. Prosentase Error Dan Keberhasilan

Gambar 3.4 merupakan proses perhitungan jumlah error pohon klasifikasi yang dibuat sebanyak 9 data mengalami error $(0,8629 \%)$ dan tingkat keberhasilannya sebesar $99,1371 \%$.

\section{Hasil Pengujian Realtime}

Pengujian pengukuran realtime dilakukan dengan percobaan selama 60 detik untuk mengetahui tingkat keberhasilan, hasil pengujian ditunjukan dengan gambar hasil pengujian dan tabel data nilai pengukuran jarak target hasil pengujian.

1. Data Hasil Pengujian

Rata-rata hasil pengujian realtime disajikan seperti pada Tabel 3.1 berikut ini:

Computer Vision Untuk Pengenalan Obyek Pada Peluncuran Roket Kendaraan Tempur (Nur Ficky Ardiansyah) 
Tabel 3.1. Hasil Pengujian Realtime

\begin{tabular}{|c|c|c|c|c|c|}
\hline No & $\begin{array}{c}\text { Jarak } \\
(\mathrm{m})\end{array}$ & $\begin{array}{c}\text { Waktu } \\
(\mathrm{dt})\end{array}$ & $\begin{array}{c}\text { Keberhasilan } \\
(\mathrm{dt})\end{array}$ & $\begin{array}{c}\text { Error } \\
(\mathrm{dt})\end{array}$ & $\begin{array}{c}\text { Persentase } \\
(\%)\end{array}$ \\
\hline 1. & 1 & 60 & 58 & 2 & $96,67 \%$ \\
\hline 2. & 1,5 & 60 & 58 & 2 & $96,67 \%$ \\
\hline 3. & 2 & 60 & 57 & 3 & $95 \%$ \\
\hline 4. & 2,5 & 60 & 57 & 3 & $95 \%$ \\
\hline 5. & 3 & 60 & 57 & 3 & $95 \%$ \\
\hline
\end{tabular}

2. Gambar Hasil Pengujian

Berikut ini adalah gambar pengujian realtime seperti ditunjukan dalam Gambar 3.5 .

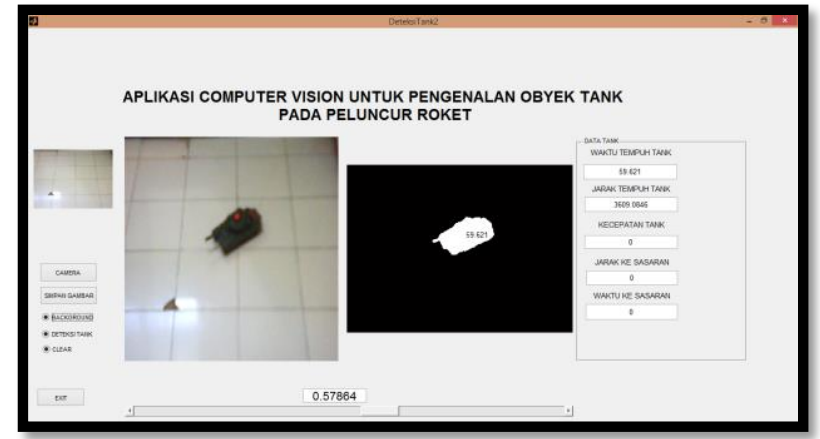

Gambar 3.5 Hasil Realtime Jarak 1 Meter

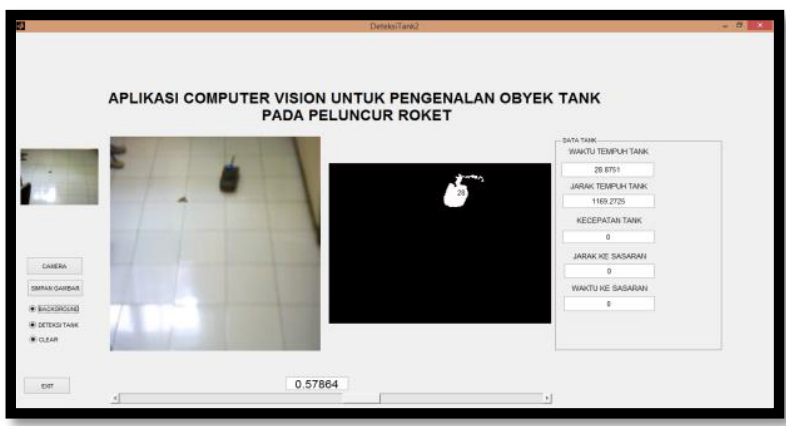

Gambar 3.6 Hasil Realtime Jarak 3 Meter

\section{Hasil Pengujian Jarak}

1. Data Hasil Pengujian ini:

Rata-rata hasil pengujian pengukuran jarak target disajikan seperti pada Tabel 3.2 berikut

Tabel 4.2. Hasil Pengujian ConvexArea Jarak Target

\begin{tabular}{|c|c|c|c|}
\hline \multirow{2}{*}{ No } & \multirow{2}{*}{$\begin{array}{c}\text { Jarak } \\
\end{array}$} & \multicolumn{2}{|c|}{ Obyek } \\
\cline { 3 - 4 } & 1 & Tank 1 & Tank 2 \\
\hline 1. & 1 & 18146 & 14074 \\
\hline 2. & 1,5 & 11062 & 10014 \\
\hline 3. & 2 & 6667 & 6395 \\
\hline 4. & 2,5 & 5217 & 5615 \\
\hline 5. & 3 & 3384 & 3702 \\
\hline
\end{tabular}

2. Gambar Hasil Pengujian

Berikut ini adalah gambar pengujian jarak target seperti ditunjukan dalam Gambar 3.7. 


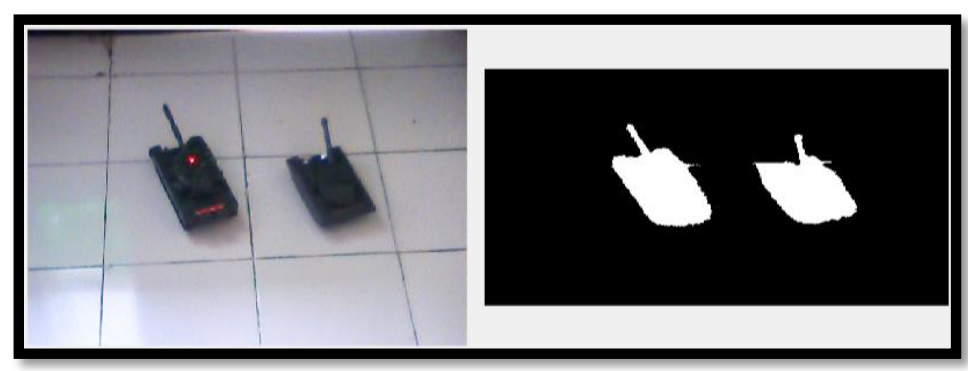

Gambar 3.7. Pengujian Jarak Target 1 Meter

\section{Hasil Pengujian Akurasi Pengenalan Obyek Tank}

1. Data Hasil Pengujian ini:

Rata-rata hasil pengujian pengukuran jarak target disajikan seperti pada Tabel 3.3 berikut

Tabel 3.3 Hasil Pengujian ConvexArea Jarak Dan Obyek

\begin{tabular}{|c|c|c|c|c|c|}
\hline \multirow{2}{*}{ No } & Jarak & \multicolumn{4}{|c|}{ Obyek } \\
\cline { 3 - 6 } & $(\mathbf{m})$ & Tank 1 & Tank 2 & Mobil & Orang \\
\hline 1. & 1 & 20927 & 19470 & 4921 & 1852 \\
\hline 2. & 1,5 & 9515 & 7970 & 3417 & 1055 \\
\hline 3. & 2 & 5982 & 5502 & 2199 & 842 \\
\hline 4. & 2,5 & 5303 & 4876 & 1808 & 0 \\
\hline 5. & 3 & 3663 & 3658 & 1350 & 0 \\
\hline
\end{tabular}

2. Gambar Hasil Pengujian

Berikut ini adalah gambar pengujian pengukuran akurasi pengenalan obyek tank dengan membandingkan tank dengan obyek obyek lain.

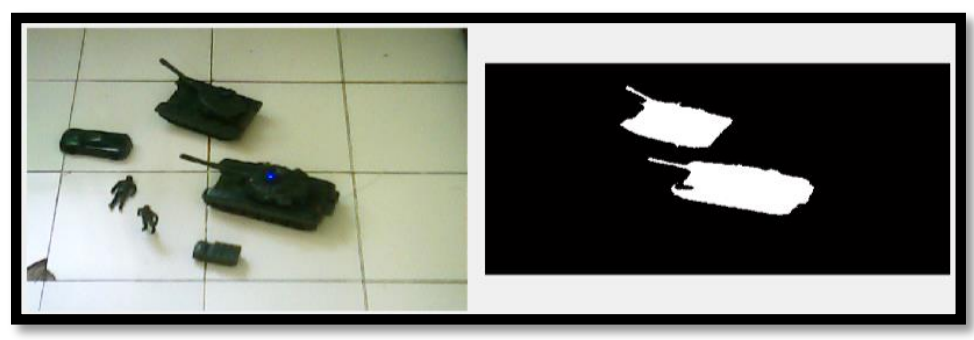

Gambar 3.8. Pengujian Akurasi Target 1 Meter

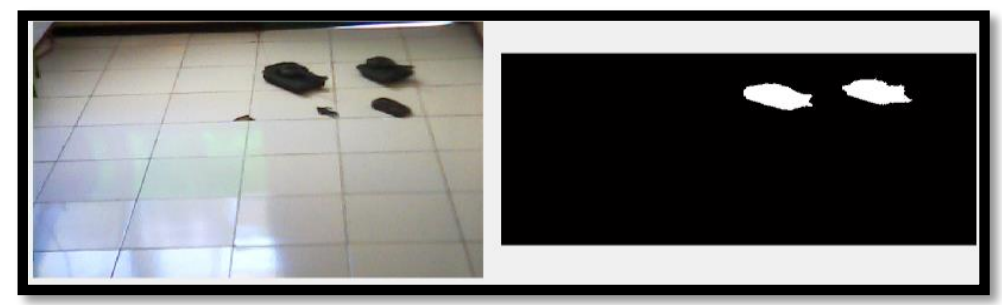

Gambar 3.9 Pengujian Akurasi Target 3 Meter

\subsection{Analisa}

Analisa Hasil Pengujian Statis

Berdasarkan pengujian statis terhadap pohon klasifikasi yang telah dibuat maka dapat dijelaskan bahwa dalam proses pengambilan data yang akan digunakan untuk pembuatan pohon klasifikasi merupakan proses yang menentukan dalam menentukan jumlah nilai error dalam pohon klasifikasi. Tempat yang digunakan, jarak kamera dengan obyek, dan pencahayaan juga merupakan factor penentu dalam pembuatan pohon klasifikasi. Semakin

Computer Vision Untuk Pengenalan Obyek Pada Peluncuran Roket Kendaraan Tempur (Nur 
banyak data yang diambil dalam proses pohon klasifikasi maka akan semakin akurat pula pohon klasifikasi.

\section{Analisa Hasil Pengujian Realtime}

Untuk menjelaskan data hasil pengujian maka dibuat grafik hasil pengujian realtime, grafik hubungan antara jarak dengan prosentase keberhasilan pengujian dapat dilihat seperti ditunjukan pada Gambar 3.10.

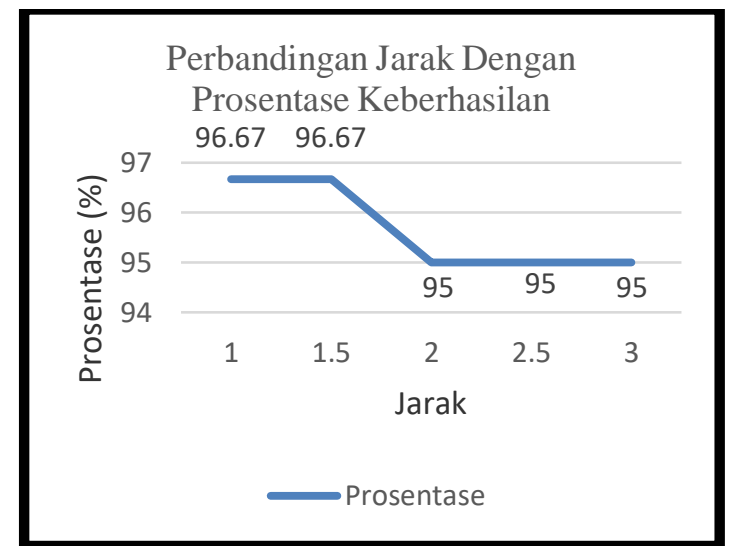

Gambar 3.10. Perbandingan Prosentase Keberhasilan Dengan Jarak

Seperti dijelaskan pada gambar 3.10 hubungan antara jarak dengan prosentase keberhasilan semakin menurun jika jarak antara obyek dengan kamera semakin jauh. Hal ini disebabkan karena semakin kecilnya obyek yang dikenali yang akan dihilangkan oleh program apabila besar pixel benda tersebut kurang dari 2000 pixel.

\section{Analisa Hasil Pengukuran Jarak}

Untuk menjelaskan data hasil pengujian maka dibuat grafik hasil pengujian pengukuran jarak target dapat dilihat seperti ditunjuhkan pada Gambar 3.11.

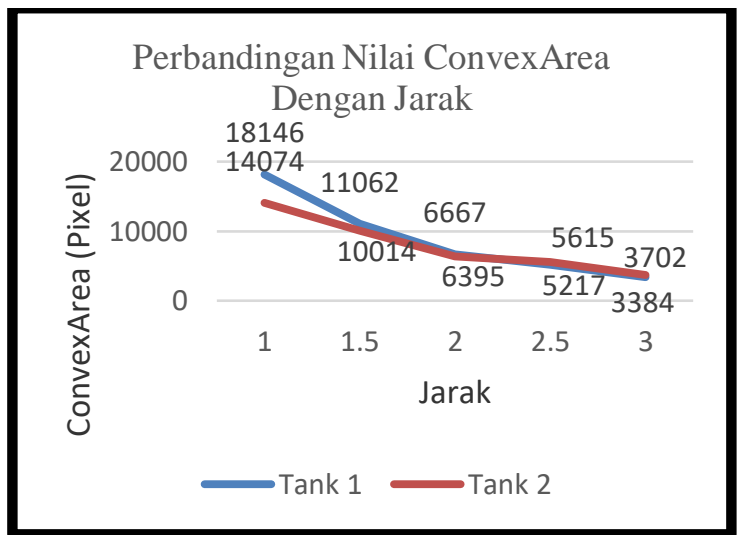

Gambar 3.11. Grafik Hubungan Jarak dengan ConvexArea

Seperti dijelaskan pada gambar 3.11 hubungan antara jarak dengan nilai ConvexArea, data yang didapat pada pengujian akurasi pengenalan obyek tank akan semakin menurun jika jarak antara kamera dengan obyek semakin jauh, hal ini dikarenakan ketika jarak kamera semakin jauh dari obyek maka obyek yang ditangkap oleh kamera akan semakin kecil sehingga dalam proses perhitungan nilai ConvexArea akan semakin kecil.

\section{Analisa Hasil Pengukuran Akurasi}

Gambar 3.12 menjelaskan nilai hasil pengukuran jarak dengan sudut elevasi. 


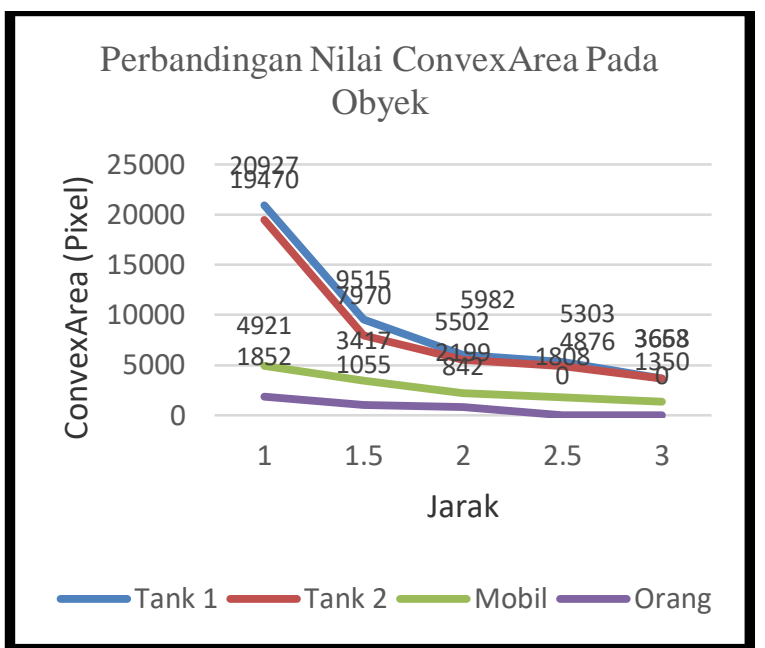

Gambar 3.12 Grafik Perbandingan Nilai ConvexArea Pada Obyek

Seperti dijelaskan pada Gambar 3.12 berdasarkan data yang didapat pada pengujian akurasi pengenalan obyek tank perbedaan yang paling mencolok yaitu pada nilai ConvexArea. ConvexArea yang akan menentukan jumlah pixel yang berada pada obyek, semakin besar obyek maka jumlah pixelnya akan semakin besar.

\section{Kesimpulan}

Dari penelitian yang telah dilaksanakan, dapat disimpulkan bahwa:

1. Dengan menggunakan metode classification trees and regression trees pada software Matlab, sistem dapat mengenali tank hingga jarak 3 meter yang dikarenakan apabila lebih dari 3 meter nilai convexarea dari obyek yang dijadikan biner oleh sistem akan lebih kecil dari standart yang telah ditentukan oleh sistem sehingga obyek akan dihapus dan tidak akan ditampilkan pada layar.

2. Dari berbagai macam penelitian menggunakan software Maltab, maka dapat disimpulkan bawa dengan menggunakan nilai - nilai pada regionprops seperti orientation, extent, convexarea, area, equivdiameter, solidity, dan perimeter dapat digunakan untuk deskriptor atau untuk membedakan tank dengan obyek lain.

\section{References}

[1] R. Wiryadinata, "Perancangan Roket Terkendali Penembak Pesawat Dilengkapi Chip Yang Terintegrasi Algoritma Cerdas," in SNATI (Seminar Nasional Aplikasi Teknologi Informasi) 2007, 2007.

[2] F. R. Hartantri and A. Pujiyanta, "Deteksi Penyakit Dan Serangan Hama Tanaman Buah Salak Menggunakan Jaringan Syaraf Tiruan (Jst) Dengan Metode Perceptron," J. Sarj. Tek. Inform., 2014.

[3] I. Mujahidin, "Directional 1900 Mhz Square Patch Ring Slot Microstrip Antenna For WCDMA," JEEMECS (Journal Electr. Eng. Mechatron. Comput. Sci., 2019.

[4] D. Coppersmith, S. E. J. Hong, and J. R. M. Hosking, "Partitioning nominal attributes in decision trees," Data Min. Knowl. Discov., 1999.

[5] I. Mujahidin, R. Yuwono, and A. Mustofa, "Rancang Bangun Rectifier Antenna Mikrostrip Ufo Pada Frekuensi Ultra Wideband (UWB) Sebagai Pemanen Energi Elektromagnetik," J. Mhs. TEUB, vol. 3, no. 2, 2015.

[6] B. Arthayaa, A. Sadiyokob, and C. Wiejaya, "Pengembangan Algoritma Pengenalan Bentuk dan Arah Objek pada Sistem Omnidirectional Vision Sensor," J. Tek. Elektro, 2013.

[7] P. Pola, K. Plat, N. Kendaraan, and D. Avianto, "Menggunakan Algoritma Momentum Backpropagation Neural Network," J. Inform., 2016.

[8] S. Rege, R. Memane, M. Phatak, and P. Agarwal, "2D Geometric Shape And Colorrecognition Usingdigital Image Processing," Int. J. Adv. Res. Electr. Electron. Instrum. Energy, 1970.

[9] I. Mujahidin, S. H. Pramono, and A. Muslim, "5.5 GHz Directional Antenna with 90 Degree

Computer Vision Untuk Pengenalan Obyek Pada Peluncuran Roket Kendaraan Tempur (Nur

Ficky Ardiansyah) 
Phase Difference Output," 2019.

[10] B. D. Puspasari, "Aplikasi Pengenalan Huruf Alfabet Bagi Anak Usia Dini Menggunakan Metode Pengolahan Citra Berbasis Data Suara," J. Eltek, 2013.

[11] R. Yuwono, I. Mujahidin, A. Mustofa, and Aisah, "Rectifier using UFO microstrip antenna as electromagnetic energy harvester," Adv. Sci. Lett., 2015.

[12] S. H. Anwariningsih, "Perhitungan Luas Dan Keliling Bangun Geometri Menggunakan Pendekatan Morfologi," Semin. Nas. Apl. Teknol. Inf. 2009 - ISSN1907-5022, 2009.

[13] T. Kobayashi and N. Otsu, "Image feature extraction using gradient local autocorrelations," in Lecture Notes in Computer Science (including subseries Lecture Notes in Artificial Intelligence and Lecture Notes in Bioinformatics), 2008.

[14] K. Matiullah, R. U. Khan, M. Dost, and R. Abdur, "Mutual effect of legume and cereal intercropping under rodkohi rainfed conditions of D.I. Khan," Sarhad J. Agric., 2005.

[15] E. Eliyani, T. Tulus, and F. Fahmi, "Pengenalan Tingkat Kematangan Buah Pepaya Paya Rabo Menggunakan Pengolahan Citra Berdasarkan Warna RGB Dengan K-Means Clustering," Singuda ENSIKOM, 2013.

[16] A. Pujiyanta, "Pengenalan Citra Objek Sederhana Dengan Jaringan Saraf Tiruan Metode Perceptron," J. Inform., 2014.

[17] E. K. Sharma, E. Priyanka, E. A. Kalsh, and E. K. Saini, "GLCM and its Features," Int. J. Adv. Res. Electron. Commun. Eng., 2015.

[18] T. Rahajoeningroem and Wahyudin, "Sistem Keamanan Rumah Dengan Monitoring Menggunakan Jaringan Telepon Selular Home Security System With Monitoring Using Cellular Phone Network," J. Tek. Elektro Unikom, 2013.

\section{Daftar Riwayat Hidup}

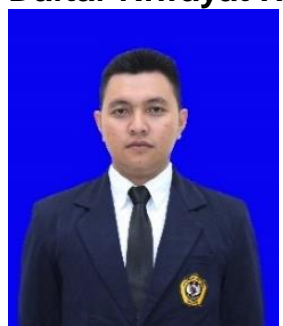

Nur Ficky Ardiansyah, lahir di Pati, 31 Agustus 1990, agama Islam. Penulis menamatkan pendidikan di SDN Palur 3 2002. Setelah itu Penulis melanjutkan pada jenjang pendidikan SLTP di SMPN 2 Margorejo dan lulus tahun 2005. Penulis melanjutkan pada jenjang pendidikan SMA di SMAN 3 Pati lulus pada 2008. Atas anugerah ALLAH SWT maka penulis dapat melanjutkan pendidikan S1 pada Jurusan Teknik Elektro UNIVERSITAS MERDEKA Malang hingga saat ini. 